\title{
THE PHYSICAL MAZE AND THE SPIRITUAL LAB YRINTH OF GIDE'S LES CAVES DU VATICAN
}

\author{
WILLIAM JENNINGS
}

The maze motif in Andre Gide's 1914 Les Caves du Vatican is too obvious in a work of such subtlety. A carefully-crafted story that intertwines a farcical swindle with the psychological study of an apparently motiveless murder - the famous acte gratuit - all the while satirizing the bourgeois family and questioning organized religion, Les Caves du Vatican takes its characters through a confusing physical and emotional journey as it deconstructs the traditional novel. Freemason scientist Anthime Armand-Dubois's experiments with rats in a maze are described in detail only four pages into the work, and announce the author's intentions to experiment in similar fashion with his nineteenth-century characters, as he puts them into a bewildering twentieth-century mental architecture. But maze and labyrinth are technically two different concepts (although the lexical distinction is not made in French, which uses labyrinthe for both): the maze is designed to puzzle, while the labyrinth is a spiritual pathway. Gide has hidden a labyrinth in the mazes that mock the scientism of the Naturalists all the while evoking classical mythology. He intertwines the physical and the spiritual in many of his works, and Les Caves du Vatican is no exception; in the opening lines, the rheumatic Anthime announces his departure for Rome to seek medical help, to which his Catholic brother-in-law Julius replies that in Rome he should be seeking a remedy for his soul, not his body. The presence of a physical maze as well as a spiritual labyrinth metaphor in Les Caves du Vatican should hardly be surprising, given Gide's lifelong attempts to reconcile his physical and spiritual selves. Indeed, it is argued in this article that the spiritual labyrinth of French cathedrals, particularly that of Chartres, offers both the key to the novel's composition and a better reading of the spatial and emotional journeys of the characters than the obvious physical mazes of the work.

The title of Les Caves du Vatican is where allusions to labyrinths and mazes begin. Caves has several possible interpretations; ut its principal meaning and the one that would first occur to the reader beginning the novel is 'cellars'. When associated with the Vatican, it suggests a catacomb-like network of ancient tunnels, but no action takes place therein. The misleading, empty title - cave also means 'hollow' - may be read as a hint that the underlying labyrinth motif is not merely physical. The Vatican cellars in the Les Caves du Vatican are mentioned only in a swindler's story, and the reader is forced to look for other meanings of cave and, perhaps, of labyrinth. By calling the work a sotie, Gide draws attention not only to the satirical intention of Les Caves du Vatican, but also associates it 
with the late medieval genre of the sotie, a blend of morality play and farce involving masked fools and religious themes set in a confusing world. This is an accurate description of the setting of Les Caves du Vatican, whose author confuses the characters by putting them in a pagan maze centred on Rome and a Christian labyrinth based on Greek mythology.

A word on the spiritual labyrinth may be necessary. Unlike the traditional physical maze, the spiritual labyrinth is unicursal. It has no walls, no dead ends, no forks, and no choices to make, although the many twists that lead almost to the centre before turning back sharply may be confusing. Labyrinths were once common in French cathedrals, but the Church destroyed most in the eighteenth and nineteenth centuries, possibly in response to the rise of Freemasonry ('le conflit entre la Loge et l'Eglise, essentiel, n'avait-il pas toujours exister), because the labyrinths evoked masons in their symmetry and paganism in their imagery. The labyrinth is not a Christian symbol. The best-known labyrinth is in Chartres cathedral and dates from the Middle Ages. ${ }^{2}$ Pilgrims enter the large circular design on the floor of the nave in search of illumination. They follow the unique sinuous path of purgation to the rose-shaped centre where they are enlightened. They then retrace their steps, emerging at the point where they entered. In medieval times the journey through the labyrinth represented a crusade for those who could not partake in the long voyage to Jerusalem (hence the alternative name chemin de Jerusalem), and instead went through the labyrinth on their knees. Remarkably, the centre of the Chartres labyrinth had for centuries an image of Theseus and the Minotaur.' A structural association with a rose window links the centre to a projected image of Christ, however. The labyrinth is the same horizontal distance from the cathedral entrance as the vertical height of the west rose window, and window and labyrinth have the same dimensions. In other words, a projection of the window onto the labyrinth overlaps exactly, and the central window depicting Christ fits precisely in the centre of the labyrinth over Theseus and the Minotaur. All these details and many more are reflected in both the composition and the characters of Les Caves du Vatican. The physical maze and the spiritual labyrinth are the two topoi of Les Caves du Vatican. Scholars have made frequent mention of the former, while treatment of the latter has been

1. Andre Gide, Les Caves du Vatican in Romans, Recits et soties, oeuvres lyriques by Andre Gide (Paris: Gallimard, Editions de la Pleiade, 1958), pp. 677-873 (p. 749). Subsequent citations from Les Caves du Vatican will be indicated by a page number in parentheses.

2. An Internet image search for chartres labyrinth' will yield many sites with a photograph or diagram of the labyrinth. The website of the Diocese of Chartres http://perso.wanadoo.fr/.diocese.chartres/cathedrale/ (accessed 6 January 2005) is one such site.

3. Bibliotheque Nationale de France, 'Le labyrinthe de Chartres', Expositions Virtuelles: Utopie (2000) http ://exp o s itions.bnf.fr/utopie/pi stes/ateliers/image/fiches/chartres.htm (accessed 6 January 2005). 
ignored. Broome draws attention to the numerous doors, windows and corridors in Les Caves du Vatican,' while Bettinson notes the disorienting effect of the mazes on the characters, and even on the reader.' 'C'est le lecteur qu'il s'amuse mystifier', says Pierre-Quint of Gide.' Van Tuyl argues that 'Gide disrupts the narrative by disrupting the characters' journeys to and from Rome." The Roman 'labyrinthe de ruelles sans nom' (p. 781) through which Allied\& Fleurissoire is led on his secret crusade to save the Pope is another maze. Two Parisian addresses associated with Lafcadio Wluiki, the irrational and independent orphan who commits a murder to remain consistently irrational, impasse Claude-Bernard and impasse Oudinot, are unusual in a city with few dead-end streets. The apartments of the Armand-Dubois in Rome and Milan, the stairways and secret door in Amedee's hotel, and the train corridors and compartments in which key events take place all reinforce the description of Anthime's 'complique systeme de boites a couloirs, a trappes, a labyrinthes' (p. 683) that he uses with his rats.

The maze and its evident links with Greek mythology feature prominently in Les Caves $d u$ Vatican. Gide might have 'left the pagan world for the world of Christian belief $[\ldots$ and...] abandoned antiquity for the contemporary age' in his early twentieth-century published works, but 'his interest in hellenism endured." References in Les Caves du Vatican to Greek mythology abound: ${ }^{2}$ the shape-changing Proteus is the master of disguise Protos; the goat-like Amedee becomes the sacrifice at a Dionysiac feast ('per Baccho' (p. 799)); the proud, haughty Antinous who throws a footstool at Odysseus and damages his shoulder is now the self-righteous Anthime who hurls his cane at the statue of the Virgin and breaks its an-n. $1^{\circ}$ Gide wrote the greater part of Les Caves $d u$ Vatican from 1911 to 1913, and at the same time was working on an interpretation of Theseus and the Minotaur. Although Thasee did not appear until 1946, Gide had referred to the Cretan myth in both Les Nourritures terrestres and Le Promethee mal enchaine, and mentioned a Thesee and the labyrinth in his journal and notes in 1911 and 1912." The

4. Peter Broome, Gide: 'Les Caves du Vatican' (London: Grant \& Cutler, 1995), pp. 25-8, 53, 70, 79, 102, 103, 111.

5. Christopher D. Bettinson, Gide: 'Les Caves du Vatican' (London: Edward Arnold, 1975), p. 43.

6. Leon Pierre-Quint, Andre Gide (Paris: Stock, 1952), p. 95.

7. Jocelyn Van Tuyl, 'All Roads lead to Rome: the Parodic Pilgrimage in Les Caves du Vatican', Romantic Review, 87:4 (1996), pp. 531-540 (p. 533).

8. Helen Watson-Williams, Andre Gide and the Greek Myth (Oxford: Clarendon Press, 1967), P. 83.

9. See William Jennings, 'Greek Mythology in Gide's Les Caves du Vatican', ms.

10. One cannot exclude as possible sources the Georgian Saint Anthime (d. 1716), who was blinded, or the Greek Saint Anthime (d. 1782) who lost and later regained his sight.

11. Andre Gide, Journal d'Andre Gide: 1889-1939 (Paris: Gallimard, Editions de la Pleiade, 1951), pp. 347, 375. 
existence of a manuscript on Theseus from about 1912 has also been signalled.12 Theseus and the labyrinth were never far from his mind during the composition of Les Caves du Vatican, and the converse is also true; in 1944, while working on Thesee, Gide wrote me semblait etre revenu au temps des Caves' ${ }^{13}$ Labyrinths form the principal nexus between the two works, although many other parallels exist. The author of Les Caves du Vatican imitates the Athenian craftsman Daedalus, not only as the architect of a labyrinth, but also as a maker of lifelike statues and 'animated wooden dolls"' - an apt description of two-dimensional characters like Anthime Armand-Dubois, who reveals his woodenness in his name. Lafcadio considers humanity to be a 'belle collection de marionnettes' (p. 823), without realizing that he is also an author's puppet. If 'les fils sont trop apparents' (p. 823), it is to show that Gide is visibly pulling the strings to stress that a character is never independent of its creator, despite his pretence of the contrary (' ...ma plume vous abandonne' (p. 723), among many other authorial interventions). Lafcadio also unwittingly refers to the strings that link the main characters of Les Caves du Vatican and cause the numerous coincidences of the book. He is unaware, for example, that the man he kills is a relative who is being watched by Lafcadio's ex-schoolfriend, is sleeping with Lafcadio's ex-mistress and is wearing jewellery Lafcadio purchased. The strings also evoke the thread Daedalus gives Ariadne to guide Theseus out of the labyrinth. The thread is traditionally interpreted as a godsend, but Gide's Theseus has a different view. The thread binds him to Ariadne, forcing him to return to her and to his past." He does not hold the thread; Ariadne 'tint a attacher elle-meme a mon poignet l'extremite du fil, par un noeud qu'elle pretendit conjugal' (Gide, Thesee (1958), p. 1438). Watson-Williams says the thread 'may be either a chain or a safety belt' ((1967), p. 139) but the latter is unlikely, since Theseus's first action is to try to cut it with his sword to see if he can free himself from the tiresome Ariadne. In Les Caves du Vatican, the cuff-links Amedee receives from Carola replace Ariadne's thread. Like the ties that bind the characters of Les Caves du Vatican to each other, the thread is unbreakable.

Amedee, whose name may parody that of Thesee, or anticipate his sacrifice by suggesting he belongs to Medea (a Medee), is an anti-Theseus. While the virile, active Theseus clears the road to Athens of bandits, the feeble, passive Amedee is a grammatical object (Van Tuyl (1996), p. 533), carried by trains to Rome and defeated on his quixotic crusade by bedbugs, fleas, a mosquito and a gang of

12. Patrick Pollard, Repertoire des lectures d'Andre Gide: L'antiquite classique (Paris: ATAG, 2000), p. 189.

13. Yvonne Davet, 'Les Caves du Vatican: notice', in Romans, Recits et soties, oeuvres lyriques by Andre Gide (Paris: Gallimard, Editions de la Pleiade, 1958), pp. 1565-77 (p. 1565).

14. Robert Graves, Greek Myths (London: Cassell, 1955), p. 293.

15. Andre Gide, Thesee in Romans, Recits et soties, oeuvres lyriques by Andre Gide (Paris: Gallimard, Editions de la Pleiade, 1958), pp. 1413-53 (p. 1433).

GIDE'S LABYRINTHS

swindlers named after a millipede. He wanders lost in the maze of his 
bewildennent and naïveté, too disorientated to take note of Carola's lifeline warning him to beware of the abbe Cave. When Amedee meets Lafcadio, he reacts identically to Theseus on encountering Gide's Minotaur; both are charmed by the beauty of the youth they believe to be sleeping. Theseus slays, but the anti-Theseus Amedee is slain.

Les Caves du Vatican had a long gestation. A year after he finished writing the book in June 1913, Gide noted that 'Les Caves du Vatican habitait depuis plus de quinze ans dans ma tete' (Journal (1951), p. 437). In a key concluding passage to his essay on 'Litterature et Morale' that dates from about the time he was beginning to compose Les Caves du Vatican, Gide writes 'En etudiant la question de la raison d'être de l'oeuvre d'art, on arrive a trouver que cette raison suffisante, ce symbole de l'oeuvre, c'est sa composition.' Again: 'le symbole, c'est autour de quoi se compose un livre' (Journal, (1951), p. 94). Les Caves du Vatican and the Chartres labyrinth are both circular, and both have a single path; Gide's characters might like to think they are independent, but are all too evidently manipulated along their path by their Daedalus. The chronology of Les Caves du Vatican is linear, despite appearances to the contrary, since events in each chapter succeed those of the previous chapter. However, the change of characters and focus from one section of the work to the next conveys simultaneity, suggesting that events converge towards a single episode. Proust, referring to Les Caves du Vatican, stated that 'les episodes convergent, composes comme dans une rose d'eglise."'6 Convergence is echoed in the novel's sections and chapters; Books 1, 2, 4 and 5 each have seven chapters and pivot around the shorter, central Book 3. This structure mirrors the Chartres labyrinth's four quadrants of seven turns converging on the centre. The numbers occur in the age of the 47-year-old Amedee Fleurissoire, who gives his name to the title of the pivotal third book. The circular shape of the labyrinth resonates in the cuff-links carved in the intricate opaque form of 'quatre tetes de chat encerclees' (p. 731), and in Julius de Baraglioul's `billet circulaire' (p. 819), both of which are in Amedee's possession at the time of his death. Amedee's walk around a Vatican fountain, when he goes downwind of the spray and smiles at the rainbow is also a complex set of arcs. The importance in Les Caves du Vatican of the collar - another circular form - has been signalled by Michael Rowland, who shows how it dominates descriptions of characters' clothing and symbolizes the bourgeois Baraglioul family." Amedee's last voluntary action is to adjust a new collar and tie. Ruth B. York describes the structure of Les Caves du Vatican as a 'multiple, interlocking circle' and notes the

16. Marcel Proust, letter to Gide, 6 March 1914 in Marcel Proust: Correspondance, 21 vols. ed. by Philip Kolb (Paris: Plon, 1970-93), XIII (1985), p. 108.

17. Michael Rowland, Tafcadio's crime revisited', French Review, 62:4 (1989), pp. 604-611.

WILLIAM JENNINGS

symbolism of the family circle,' echoed by Maucuer's comment that 'le premier cercle est celui de la famille.' '9 
The Chartres labyrinth's location divides the seven bays of the cathedral nave into four and three: 'quatre et trois, sept : le chiffre est bon,' observes Lafcadio, who pretends to let numbers determine his choices, when walking to the Baragliouls' apartment at 34, me de Verneuil (p. 732). The twelve circles of the labyrinth are indicated many times in Les Caves du Vatican. Lafcadio's address is 12, impasse Claude-Bernard and he counts to 12 to decide whether or not to push Amedee from the train (counting to ten would be more natural). Amedee, whose cuff-links cost Lafcadio 120 francs, remarks of people in the street that 'il n' en est pas quatre sur douze dont l'occupation saute aux yeux' (p. 796).

The four principal characters of Les Caves du Vatican all have a definite moment of entry into their spiritual labyrinth. Amedee leaves Pau, Anthime attacks the statue of the Virgin, Julius meets Lafcadio, and Lafcadio learns that he belongs to a family." The movements and behaviour of the characters of Les Caves du Vatican are more suggestive of a labyrinth rather than a maze. When pilgrims enter the Chartres labyrinth they proceed directly towards the centre, make a left turn, double back and then arrive at the edge of their destination, unable to advance any further in a straight line. They must then shuttle to and fro many times before finally arriving at the centre. This describes exactly the path of Amedee Fleurissoire. A parody of the impoverished Christian knight errant whom Carola calls 'le pelerin' (p. 786), Amedee takes the wrong train on his journey from Pau to Rome, making in effect a left turn at Marseille, before doubling back and continuing to Rome. He does traverse a Roman 'labyrinthe de ruelles sans nom' (p. 781), but has a guide, Baptistin, who takes him directly through the maze. Amedee arrives at the edge of his destination, the chateau Saint-Ange where he believes the Pope is imprisoned, but cannot get past the walls. From that moment, his life is a journey of oscillations. 'Devant le pont-levis de l'entree, it passait, repassait...' (p. 789). He walks to and fro past Protos three times, before the latter reveals his (false) identity and begins to shadow him, thereby also oscillating. He 'faisait les cent pas' in the station in front of the train to Naples (p. 795). After the sorry episode at the Neapolitan barber's, he runs back to a pharmacy then back past the barber's. He returns to Rome that evening, rushes back to the Post Office the next day, scurries to the Vatican where he 'fit le tour de la fontaine' (p. 811). Even after his death on the train to Naples, Amedee's movements continue. His body, his ticket, a cufflink and a piece of his clothing all return to Rome in different ways. Numerous verbs with the

18. Ruth B. York, 'Circular Patterns in Gide's "Soties--, French Review, 34:4 (1961), pp. 336343 (pp. 337, 343).

19. Maurice Maucuer, Gide: L'indecision passionnee, (Paris: Le Centurion, 1969), p. 70.

20. See Elaine D. Cancalon, 'La structure du systeme dans Les Caves du Vatican: approches sêmique, fonctionnelle et formelle', Revue des Lettres Modernes: Andre Gide, 7 (1984), pp. 117-44 (p. 130).

GIDE'S LABYRINTHS

prefix 're-' illustrate the shuttling in the labyrinth, among them: 'repassait' (p. 789), 'revenir' (p. 794), `retrouver' (p. 797), 'retournee (p. 798), 'redescendant' (p. 799), 'remonta' (p. 799), 'regagna' (p. 807). Amedee himself sums it up: 'Je me suis 
retourne maintes fois' (p. 795). Never reaching the centre of his physical labyrinth, Amedee attains a spiritual centre where he undergoes a parodic enlightenment: a supreme moment of disbelief when he doubts his own reality. His reality is illusion, and he never comprehends it. Amedee dies in ignorance of the fact that the crusade to save the Pope, his reason for entering the labyrinth, is a hoax. In Rome Anthime, whose guide is the street-urchin Beppo, attains enlightenment through a conversion to Catholicism after a confused dream of his niece as the Virgin Mary and the miraculous cure of his twisted spine (a miracle probably triggered when he hurled his crutch in fury at the statue of the Virgin). In any case, the conversion is short-lived, and Anthime returns on the outward path just as bitter an atheist as when he went in. Like Anthime, the pompous bourgeois author Julius de Baraglioul has his moment of spiritual enlightenment in Rome. Leaving Paris for Rome, he makes a brief detour to visit his converted brother-in-law, before having an audience, on his knees, with the Pope, whom he sees only after passing through a bewildering number of Vatican antechambers. Julius's revelation, triggered by his encounters with the unconventional Lafcadio outside bourgeois society, occurs as he is at the centre of the labyrinth, bowing to the Pope. He is inspired to challenge orthodox society and create an unconventional, irrational character in a new novel. But once he believes that a false Pope is in the Vatican, the brighter, passionate incarnation of Julius returns to his dull, aristocratic former self. Even the gambling Lafcadio follows a single path, pretending to let chance decide his movements, but ignoring what chance decides. He decides to spare Amedee if he can count to twelve before seeing a light in the countryside, but pauses and slows the count to distort the odds in his favour. In Capua he rolls a die to determine his next move. ' $\mathrm{Si} \mathrm{j}$ jamene six, se dit-il en sortant le de, je descends !" Il amena cinq. "Je descends quand meme"' (p. 831). Lafcadio's movements in Paris reflect the sinuous pathway of the spiritual labyrinth, as his route is never direct. He likes to think he is free to choose his route, but there is always a reason for his behaviour: Tar amour du detour [...] Lafcadio prenait par le plus long ; it avait suivi le boulevard des Invalides, etait repasse pros du theatre de l'incendie' (p. 732). In this case, the reason is not so much love of detours as hoping to see Genevieve de Baraglioul again. Lafcadio's murder of Amedee is the centre of the physical maze, where Theseus encounters the Minotaur, and also the centre of Lafcadio's spiritual labyrinth. The invisible ties binding him to the Baraglioul family take him to Rome, where he becomes a member of the family, spiritually, by giving it a skeleton in the closet to hide when he confesses to Julius that he is the murderer, and physically, by sleeping with Genevieve. Will he leave the family and become the Lafcadio of old, or will he now remain a bourgeois Baraglioul? Gide has left the ending open, with Lafcadio still at the centre of the labyrinth as the book concludes. 
The maze of Knossos and the labyrinth of Chartres form a nexus in Les Caves $d u$ Vatican between the physical and the spiritual, the pagan and the Christian. The complex geometry of the work constructed by a master craftsman hints at a Daedalus or at the builder of a cathedral. The characters move through the labyrinth 'de ricochet en ricochet"' on their chemin de Jerusalem that has become a road to Rome, and towards a centre where the Christ of light and enlightenment is a vacuum: a non-existent false Pope and an ephemeral false enlightenment. The plot of Les Caves $d u$ Vatican may be full of unlikely coincidences, but the similarity of Gide's careful composition to the spiritual labyrinth is not due to chance. 